\title{
A concise synthesis of Fingolimod: an orally available drug for treating multiple sclerosis
}

\author{
Ning Yan $^{1+}$, Kai Chen $^{1+}$, Xinfa Bai ${ }^{1+}$, Lei Bi ${ }^{2 *}$ and Lei Yao ${ }^{1 *+}$
}

\begin{abstract}
A concise route for the synthesis of Fingolimod is reported. Starting from n-octylbenzene and 3-nitropropionic acid, a sequence of reactions consisting of Friedel-Crafts acylation, reduction, and double Henry reaction, followed by hydrogenation were applied to prepare Fingolimod with a yield of 31\%, and an overall atom economy of $82.7 \%$.
\end{abstract}

Keywords: Fingolimod, 3-nitropropionic acid, Immunosuppressant

\section{Findings}

Fingolimod (1, FTY-720) was first synthesized in 1992 $[1,2]$. It is an immunomodulating drug, and was approved for treating multiple sclerosis(MS) in 2010. Fingolimod is a sphingosine 1-phosphate receptor modulator precursor that becomes active in vivo following phosphorylation by sphingosine kinase 2 to form Fingolimod-phosphate. This phosphate moiety binds to extracellular $\mathrm{G}$ protein-coupled receptors, sphingosine 1-phosphates and prevents the release of lymphocytes from lymphoid tissue thus preventing them from contributing to an autoimmune reaction. This process could lead to a neural protection and restoration process, and can reduce MS recurrence rate, slow down the progression of damage, reduce intracranial magnetic resonance imaging (MRI), the number of lesions, and reduce the severity of the lesions [3,4].

Structurally, Fingolimod could be divided into three parts: the hydrophobic $n$-octyl side chain (A), the planar aromatic ring with a two carbon linker (B), and the hydrophilic amino-alcohol terminal (C, Figure 1).

To date, several synthetic routes for Fingolimod have been reported [5-15]. However, these synthetic methods were unsuitable to industrial scale-up mainly due to the involvement of multiple steps and dangerous chemicals such as lithium aluminium hydride (LAH).

Discovery of efficient synthetic methods for active pharmaceutical ingredients is always a medicinal chem-

\footnotetext{
*Correspondence: lei_bi@hotmail.com; yaoleiytu@163.com

${ }^{\dagger}$ Equal contributors

${ }^{2}$ School of Chemistry and Chemical Engineering, Anhui University of

Technology, Maanshan, Anhui 243002, China

${ }^{1}$ School of Pharmacy, Yantai University, Yantai, Shandong 264005, China
}

ist's interest. During our investigation for the application of 3-nitropropionic acid as synthetic building block, we envisioned that compound 4 (Scheme 1) could be a key intermediate in the synthesis of Fingolimod. This compound could be obtained by other synthetic routes reported in literatures [16]. Herein, we report a concise synthesis of Fingolimod, which is economically sound and easy to operate.

Treatment of the commercially available n-octylbenzene (2) with 3-nitropropanoyl chloride under $\mathrm{AlCl}_{3}$ gave compound $\mathbf{4}$ with good yield (85\%). The gem-hydroxylmethyl moiety was introduced to compound $\mathbf{4}$ on the alpha carbon to form intermediate $\mathbf{7 b}$, and then the nitro group and carbonyl group were reduced simultaneously in one single step. However, the reaction of compound 4 with formaldehyde (or equivalent) was messy, and no clean $\mathbf{7 b}$ could be isolated. We ascribed the failure to the presence of the carbonyl group, which might cyclize with the hydroxyl group generated in the Henry reaction, or form a cyclopropanol when it was intra-molecularly attacked by the $\alpha$-carbon anion. Therefore, we tried to reduce the carbonyl group before the Henry reaction. Thus, treatment of compound $\mathbf{4}$ with triethylsilane and TFA gave compound $\mathbf{6}$ with high yield (98\%). Compound 6, which contained only one acidic site, could be easily converted to compound $7 \mathrm{a}$ by a double Henry type reaction by treatment with formaldehyde under basic condition [1]. To complete the synthesis of Fingolimod (1), the nitro group in compound 7a was reduced to amine, followed by a salt formation.

As described above, compound $6[6,17]$ was the key intermediate in the synthesis of Fingolimod. We also tried an alternative way to prepared it. In this route, a 


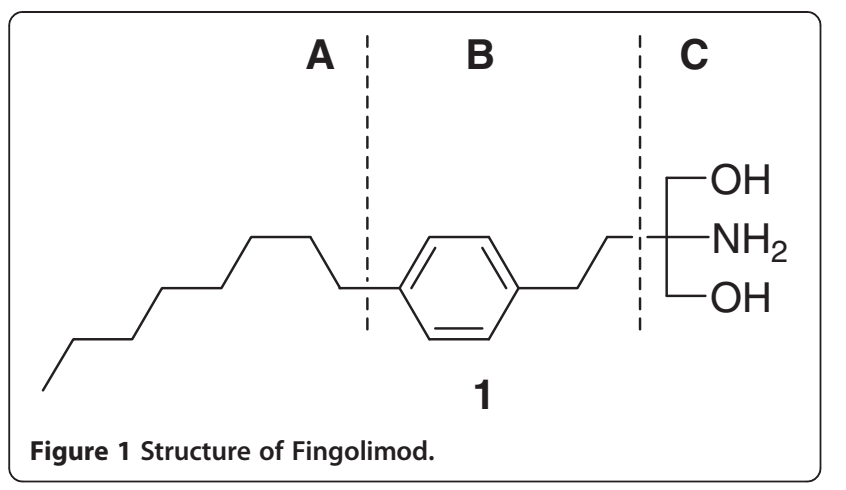

much cheaper 3-bromopropionic acid was used instead of the relatively more expensive 3-nitropropionic acid. Thus, compound 3 was obtained by treatment of $n$ octylbenzene with 3-bromopropanoyl chloride under the presence of $\mathrm{AlCl}_{3}$. However, the direct displacement of the $\mathrm{Br}$ group to a $\mathrm{NO}_{2}$ group in compound 3 to form compound 4 using sodium nitrate and DMF failed, because the reason might be that the $\mathrm{Br}$ is a good leaving group, and the elimination of $\mathrm{HBr}$ to form an enone rather the nucleophilic substitution was preferred for compound 3. To avoid the elimination reaction, a two-step operation was adopted to convert compound 3 to 6 by first reducing the carbonyl group by triethylsilane to form compound 5, and then a $\mathrm{S}_{\mathrm{N}} 2$ displacement reaction to yield 6 . The yield of the $\mathrm{S}_{\mathrm{N}} 2$ displacement reaction was low under un-optimized conditions because some nitrite product was isolated.
In summary, a concise route for the synthesis of Fingolimod was reported from commercially available $n$ octylbenzene in 4 steps with an overall yield of $31 \%$, and the atom economy for the whole route was $82.7 \%$.

\section{Description of additional material}

3-Bromo-1-(4-octylphenyl)propan-1-one (3)

To a flame-dried $500 \mathrm{~mL}$ 4-necked flask, was charged n-octylbenzene $24.39 \mathrm{~g}(0.128 \mathrm{~mol})$, hexane $158 \mathrm{~mL}$, and the reaction mixture was cooled to $5^{\circ} \mathrm{C}$. To this mixture, a solution of 3-bromopropanyl chloride $25.0 \mathrm{~g}$ $(0.146 \mathrm{~mol})$ was added dropwise, followed by addition of $\mathrm{AlCl}_{3} 19.55 \mathrm{~g}(0.147 \mathrm{~mol})$ in portion to control the reaction temperature under $10^{\circ} \mathrm{C}$. The reaction mixture was allowed to stir at $0^{\circ} \mathrm{C}$ for $0.5 \mathrm{~h}$, room temperature for $1 \mathrm{~h}$, then reflux for $0.5 \mathrm{~h}$. The reaction mixture was poured into a water-crushed-ice solution with vigorous stirring, the precipitate was collected and washed with water. The filtrate was extracted by ethyl acetate, and the combined organic phase was concentrated. The solid was combined and re-crystallized in petroleum ether to afford an offwhite solid 31 g. yield:74.3\%. M.p.:38-40 $0^{\circ} \mathrm{C} .{ }^{1} \mathrm{H}$ NMR $\left(400 \mathrm{MHz}, \mathrm{CDCl}_{3}\right) \delta 7.11(\mathrm{~m}, 4 \mathrm{H}), 3.32(\mathrm{t}, J=4.0 \mathrm{~Hz}, 2 \mathrm{H})$, $3.13(\mathrm{t}, J=4.0 \mathrm{~Hz}, 2 \mathrm{H}), 2.56(\mathrm{t}, J=4.0 \mathrm{~Hz}, 2 \mathrm{H}), 1.59$ $(\mathrm{m}, 2 \mathrm{H}), 1.23-1.35(\mathrm{~m}, 10 \mathrm{H}), 0.87(\mathrm{t}, J=6.8 \mathrm{~Hz}, 3 \mathrm{H}) ;{ }^{13} \mathrm{C}$ NMR $\left(\mathrm{CDCl}_{3}\right) \delta 198.8,143.1,132.6,128.4,128.1,42.8$, $36.0,31.8,31.3,29.8,29.4,29.2,26.5,22.5,14.3$.

\section{1-Bromo-3-(4-octylphenyl)propane (5)}

To a flam-dried $250 \mathrm{~mL}$ 4-necked flask, was added $7.92 \mathrm{~g}(24.4 \mathrm{mmol})$ of compound 3 and $18.6 \mathrm{~mL}$ TFA.

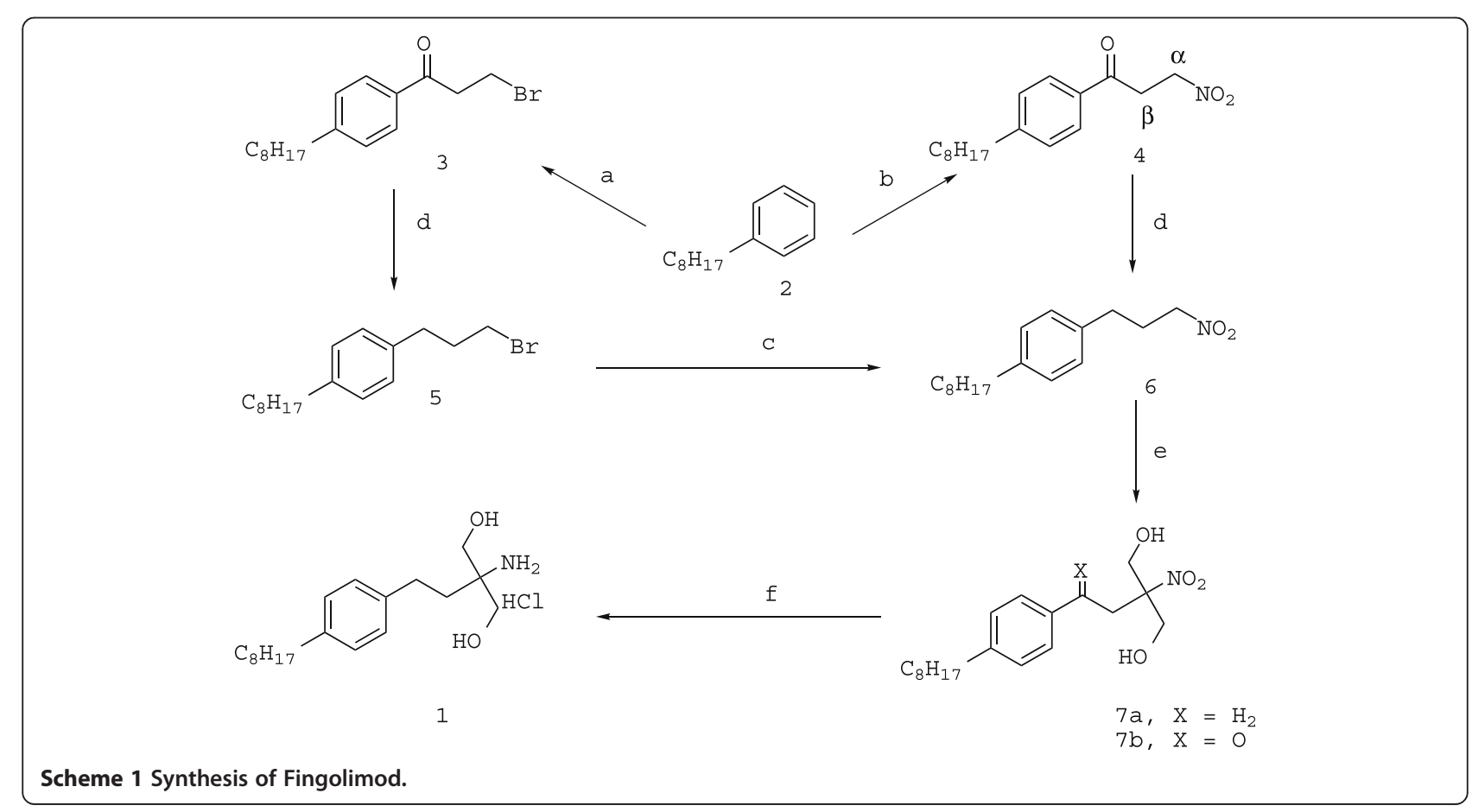


The reaction mixture was cooled to $10^{\circ} \mathrm{C}$, and a solution of $5.65 \mathrm{~g}(48.7 \mathrm{mmol})$ of triethylsilane was added dropwise. The reaction mixture was allowed to stir at $10^{\circ} \mathrm{C}$ for $30 \mathrm{~min}$, and then at room temperature for $4 \mathrm{~h}$. The reaction mixture was poured into water with crushed-ice under vigorous stirring, and the $\mathrm{pH}$ was adjusted to 8 by $\mathrm{NaHCO}_{3}$. The mixture was extracted by petroleum ether $100 \mathrm{~mL} \times 3$, and the organic phase was combined, washed with brine, dried by $\mathrm{Na}_{2} \mathrm{SO}_{4}$, filtered, and concentrated to afford a yellow liquid, which was subjected to flash chromatography (EA:Hex $=1: 8)$ to afford a colorless oil (7.46 g. Yield: $98.4 \%) .{ }^{1} \mathrm{H}$ NMR $\left(400 \mathrm{MHz}, \mathrm{CDCl}_{3}\right) \delta$ $7.12(\mathrm{~s}, 4 \mathrm{H}), 3.18(\mathrm{t}, J=8.0 \mathrm{~Hz}, 2 \mathrm{H}), 2.90(\mathrm{t}, J=4.0 \mathrm{~Hz}$, $2 \mathrm{H}), 2.57(\mathrm{t}, J=4.0 \mathrm{~Hz}, 2 \mathrm{H}), 1.54-1.67(\mathrm{~m}, 4 \mathrm{H}), 1.24-$ $1.34(\mathrm{~m}, 10 \mathrm{H}), 0.88(\mathrm{t}, J=6.8 \mathrm{~Hz}, 3 \mathrm{H}) ;{ }^{13} \mathrm{C}$ NMR $\left(\mathrm{CDCl}_{3}\right) \delta 136.1,133.6,128.4,128.0,36.1,34.4,33.4$, 31.9, 31.3, 29.7, 29.4, 29.2, 28.8, 22.5, 14.1 .

\section{Nitro-3-(4-octylphenyl)propane (6)}

Method A: To a mixture of $9.59 \mathrm{~g}(30.8 \mathrm{mmol})$ of compound 5 and $44 \mathrm{~mL}$ of DMF, was added $8.47 \mathrm{~g}$ $(122.8 \mathrm{mmol})$ of $\mathrm{NaNO}_{2}$ at $0^{\circ} \mathrm{C}$. The reaction mixture was allowed to stir at $0^{\circ} \mathrm{C}$ for $0.5 \mathrm{~h}$, then at room temperature for $6 \mathrm{~h}$. The reaction mixture was poured into $200 \mathrm{~mL}$ of iced-water, extracted with petroleum ether $100 \mathrm{~mL} \times 3$. The organic layer was combined, washed with brine, dried by $\mathrm{Na}_{2} \mathrm{SO}_{4}$, filtered, and concentrated to afford a yellow liquid, which was purified by flash chromatography (EA: Hex $=1: 8)$ to afford a colorless oil (3.00 g. Yield: 35.1\%). Method B: By the same procedures as described in making compound $\mathbf{5}$ using compound $\mathbf{4}$ and triethylsilane as reactants. ${ }^{1} \mathrm{H}$ NMR $\left(400 \mathrm{MHz} \mathrm{CDCl}_{3}\right) \delta$ 7.07-7.13 (m, 4H), $4.36(\mathrm{t}, J=7.2 \mathrm{~Hz}, 2 \mathrm{H}), 2.69(\mathrm{t}, J=7.5 \mathrm{~Hz}, 2 \mathrm{H}), 2.57(\mathrm{t}, J=$ $4.0 \mathrm{~Hz}, 2 \mathrm{H}), 2.31(\mathrm{~m}, 2 \mathrm{H}), 1.55-1.61(\mathrm{~m}, 2 \mathrm{H}), 1.24-1.34$ $(\mathrm{m}, 10 \mathrm{H}), 0.88(\mathrm{t}, J=7.0 \mathrm{~Hz}, 3 \mathrm{H}) ;{ }^{13} \mathrm{C}$ NMR $(\mathrm{CDCl} 3) \delta$ 139.8, 139.1, 128.4, 128.2, 89.5, 63.3, 36.1, 31.9, 31.3, 29.7, 29.4, 29.2, 28.83, 28.81, 22.5, 14.1.

\section{3-Nitro-1-(4-octylphenyl)propan-1-one (4)}

Compound 4 was prepared by the same method as described in the preparation of compound 3 using $n$ octylbenzene and 3-nitropropanoyl chloride (making from 3-nitropropanoic acid [18] and thionyl chloride) as starting material. Yield: $85 \% .{ }^{1} \mathrm{H}$ NMR $(400 \mathrm{MHz}$ $\left.\mathrm{CDCl}_{3}\right) \delta 7.07-7.13(\mathrm{~m}, 4 \mathrm{H}), 4.36(\mathrm{t}, J=7.2 \mathrm{~Hz}, 2 \mathrm{H})$, $2.69(\mathrm{t}, J=7.5 \mathrm{~Hz}, 2 \mathrm{H}), 2.57(\mathrm{t}, J=4.0 \mathrm{~Hz}, 2 \mathrm{H}), 2.31$ (m, 2H), 1.55-1.61 (m, 2H), 1.24-1.34 (m, 10H), 0.88 $(\mathrm{t}, J=7.0 \mathrm{~Hz}, 3 \mathrm{H}) ;{ }^{13} \mathrm{C}$ NMR $\left(\mathrm{CDCl}_{3}\right) \delta 139.8,139.1$, $128.4,128.2,89.5,63.3,36.1,31.9,31.3,29.7,29.4$, $29.2,28.83,28.81,22.5,14.1$.

\section{2-Nitro-2-(4-octylphenylethyl)propane-1,3-diol (7a)}

To a four-necked round bottom of flask, was added $0.6 \mathrm{~g}$ (2.17 mmol) of compound 6 and $10 \mathrm{~mL}$ 1,4-dioxane, then
$3.3 \mathrm{~g}$ of polyformaldehyde and 4 drops of TEA. The reaction was allowed to stir at $70^{\circ} \mathrm{C}$ for $4 \mathrm{~h}$ till all starting material was consumed. The solvent was removed under reduced pressure, and the residue was purified by flash chromatography (EA:Hex =1:3) to afford the title compound as a white solid. Yield: $41.1 \%$, M.P.: $99-101^{\circ} \mathrm{C} .{ }^{1} \mathrm{H}$ $\operatorname{NMR}\left(400 \mathrm{MHz}, \mathrm{CDCl}_{3}\right) \delta: 7.09(\mathrm{~d}, J=8.0 \mathrm{~Hz}, 2 \mathrm{H})$, $7.06(\mathrm{~d}, J=8.0 \mathrm{~Hz}, 2 \mathrm{H}), 4.24(\mathrm{~d}, J=12.0 \mathrm{~Hz}, 2 \mathrm{H}), 4.06$ $(\mathrm{d}, J=12.0 \mathrm{~Hz}, 2 \mathrm{H}), 2.53-2.57(\mathrm{~m}, 4 \mathrm{H}), 2.16-2.20(\mathrm{~m}$, $2 \mathrm{H})$, 1.54-1.59 (m, 2H), $1.24-1.34(\mathrm{~m}, 10 \mathrm{H}), 0.84(\mathrm{t}, J=$ $6.0 \mathrm{~Hz}, 3 \mathrm{H}) ;{ }^{13} \mathrm{C}$ NMR $\left(\mathrm{CDCl}_{3}\right) \delta 136.1,133.6,128.4,128.0$, 75.1, 36.1, 33.4, 31.9, 31.3, 29.7, 29.4, 29.2, 28.8, 22.5, 14.1 .

\section{2-Amino-2-(4-octylphenylethyl)propane-1,3-diol HCl (1)}

To a $100 \mathrm{~mL}$ reactor, was added $0.3 \mathrm{~g}(0.89 \mathrm{mmol})$ of compound $7 \mathbf{a}, 10 \mathrm{~mL}$ of ethanol, and $30 \mathrm{mg}$ of $10 \%$ $\mathrm{Pd} / \mathrm{C}$. The reaction mixture was allowed to stir at room temperature for $15 \mathrm{~h}$ under a $0.3 \mathrm{MPa}$ hydrogenation condition. The reaction was filtered through a pad of Celite, and washed with ethanol. The combine filtrate was concentrated under reduced pressure to afford a white solid, which was treated with $20 \mathrm{~mL}$ of saturated $\mathrm{HCl}$ in ethanol, and the plate solid $(0.28 \mathrm{~g})$ was collected as the salt form of the title compound. Yield : 92\%. M.p.: $106 \sim 108^{\circ} \mathrm{C}$ (lit.107-108 ${ }^{\circ} \mathrm{C}$ ). ${ }^{1} \mathrm{H}$ NMR $\left(400 \mathrm{MHz}, \mathrm{CDCl}_{3}\right)$ 8: 7.08 (s, 4H, Ar-H), $3.62(\mathrm{~s}, 2 \mathrm{H}), 3.54$ $(\mathrm{s}, 2 \mathrm{H}), 2.52-2.60(\mathrm{~m}, 8 \mathrm{H}), 1.69-1.70(\mathrm{~m}, 2 \mathrm{H}), 1.57(\mathrm{~m}, 2 \mathrm{H})$, $1.20-1.25(\mathrm{~m}, 10 \mathrm{H}), 0.87(\mathrm{t}, J=6.0 \mathrm{~Hz}, 3 \mathrm{H}) ;{ }^{13} \mathrm{C} \mathrm{NMR}$ $\left(\mathrm{CDCl}_{3}\right) \delta 139.8,139.1,128.3,128.2,61.1,60.5,34.9,33.4$, $31.4,31.2,29.0,28.83,28.81,28.1,22.2,14.1$.

\section{Abbreviations}

TEA: Triethylamine; TFA: Trifluroacetic acid; DMF: N,N-Dimethylformamide; $\mathrm{S}_{\mathrm{N}}$ 2: Nucleophilic Substitution.

\section{Competing interests}

The authors declare that they have no competing interests.

\section{Authors' contributions}

YN and CK performed the synthesis of Fingolimod and helped the drafting of the manuscript. BXF carried out the preparation of 3-nitropropanoic acid. $B L$ and $Y L$ conceived the study, participated in its design, and coordinated and helped to draft the manuscript. All authors read and approved the final manuscript.

\section{Acknowledgements}

The author thanks the support by a grant of Shandong Blue-economic-zones Talent Project (2012); the Natural Science Research Program for Higher Education, Key Program, Educational Commission of Anhui Province, China (Grant No. KJ2013A062) and Training Programs of Innovation and Entrepreneurship for College Students of Anhui Province, China (Grant No. AH201310360280).

Received: 29 August 2014 Accepted: 13 January 2015

Published online: 01 February 2015

References

1. Adachi K, Kohara T, Nakao N, Arita M, Chiba K, Mishina T, et al. Design, synthesis, and structure-activity-relationship of 2-substituted-2-amino-1,3propanediols:discovery of a novel immunosuppressant, FTY720. Bioorg Med Chem Lett. 1995;5:853. 
2. Strader CR, Pearce CJ, Oberlies NH. Fingolimod (FTY720): a recently approved multiple sclerosis drug based on a fungal secondary metabolite. J Nat Prod. 2011;74:900.

3. Mandala S, Hajdu R, Bergstrom J, Quackenbush E, Xie J, Milligan J, et al. Alteration of lymphocyte trafficking by sphingosine-1-phosphate receptor agonists. Science. 2002;296:346.

4. Brinkmann V, Davis MD, Heise CE, Albert R, Cottens S, Hof R, et al. The immune modulator FTY720 targets sphingosine-1-phosphate receptors. J Biol Chem. 2002;277:21453.

5. Durand P, Peralba P, Sierra F, Renaut P. A new efficient synthesis of the immunosuppressive agent FTY-720. Synthesis. 2000;4:505-6.

6. Kalita B, Barua N, Bezbarua M, Bez G. Synthesis of 2-nitroalcohols by regioselective ring opening of epoxides with $\mathrm{MgSO}_{4} / \mathrm{MeOH} / \mathrm{NaNO}_{2}$ system: a short synthesis of immunosuppressive agent FTY-720. Synlett. 2001;9:1411.

7. Seidel G, Laurich D, Fürstner A. Iron-catalyzed cross-coupling reactions: a scalable synthesis of the immunosuppressive agent FTY720. J Org Chem. 2004;69:3950.

8. Mei T, Luo Y, Feng X, Lu W, Yang B. Suzuki coupling based synthesis and in vitro cytotoxic evaluation of Fingolimod and analogues. Tetrahedron. 2013;69:2927.

9. Kim S, Lee H, Lee M, Lee T. Efficient synthesis of the immunosuppressive agent FTY720. Synthesis. 2006;5:753.

10. Hale J, Yan L, Neway W, Hajdu R, Bergstrom J, Milligan J, et al. Synthesis, stereochemical determination and biochemical characterization of the enantiomeric phosphate esters of the novel immunosuppressive agent FTY720. Bioorg Med Chem. 2004;12:4803.

11. Hale J, Neway W, Mills S, Hajdu R, Keohane A, Rosenbach M, et al. Potent S1P receptor agonists replicate the pharmacologic actions of the novel immune modulator FTY720. Bioorg Med Chem Lett. 2004;14:3351.

12. Hinterding K, Cottens S, Albert R, Zecri F, Buehlmayer P, Spanka C, et al. Synthesis of chiral analogues of FTY720 and its phosphate. Synthesis. 2003. p. 1667.

13. Feng $X$, Yang $X$, Luo $Y, L i X$, Tang $W$, Zuo J, et al. Synthesis and immunomodulating activity of new analogues of Fingolimod. Arch Pharm Chem Life Sci. 2012;345:93.

14. Mulakayala N, Rao P, Iqbal J, Bandichhor R, Orugant S. Synthesis of novel therapeutic agents for the treatment of multiple sclerosis: a brief overview. Eur J Med Chem. 2013;60:170

15. Kandagatla B, Raju W, Kumar NS, Reddy GM, Srinivas K, lqbal J, et al. Practical synthesis of fingolimod from diethyl acetamidomalonate. RSC Adv. 2013;3:9678.

16. Compound 4 has been reported in the following patents: WO2012146980; WO2012056458; CN1765872.

17. In patent WO2012/146980, the compound 6 was obtained by a similar sequence: Friedel-Crafts reaction of $n$-octylbenzene and 3 -chloropropanyl chloride, then displacement of $\mathrm{Cl}$ with nitro group, followed a reduction of carbonyl by triethylsilane and $\mathrm{TiCl}_{4}$.

18. 3-nitropropionic acid is toxic especially to the central nervous system Fortunately, it is solid and easily to handle. The operator was strongly recommended to ware glove and mask.

\section{Publish with ChemistryCentral and every scientist can read your work free of charge \\ "Open access provides opportunities to our colleagues in other parts of the globe, by allowing anyone to view the content free of charge." \\ W. Jeffery Hurst, The Hershey Company. \\ - available free of charge to the entire scientific community \\ - peer reviewed and published immediately upon acceptance \\ - cited in PubMed and archived on PubMed Central \\ - yours - you keep the copyright \\ Submit your manuscript here: \\ http://www.chemistrycentral.com/manuscript/<smiles>c1ccccc1</smiles> \\ Chemistry Central}

